\title{
The Librarians' Agenda of Unfinished Business
}

\section{Dr. Evans is Librarian of Congress.}

T GIVEs me much pleasure to meet with 1 you on the occasion of the dedication of this magnificent library addition. It is a resource of which Ohio State University can be proud. It marks a further step forward in the recognition of the library as a vital center in university and community life. It has been a long and uphill climb to the concept of the library serving as the laboratory of the scholar and the investigator, with the librarian having a vital responsibility in the processes of research by acquiring, processing and servicing the record of the successes and failures of all previous researches. And in many quarters the goal has not been reached.

Librarians today have greater collections, faster processes, better buildings, more and better trained personnel and larger budgets than ever before. The building we are dedicating today recognizes and makes a place for these advances and achievements. Yet these things are mere steps in a path of progress which has long stretches ahead. The resources and the capacities librarians now have at their command are such that by responding energetically to the needs which are pressing upon them, they can make a great stride forward in the usefulness of their services and make a great demonstration of their intimate involvement

1 An address delivered on the occasion of the dedication of the William Oxley Thompson Memorial Library, Ohio State University, Columbus, June I, I95 I. in all aspects of intellectual activity and growth. The present recognition of the library's role is sufficient, it seems to me, to assure that the librarians of this country will be called upon in the years immediately ahead to expand their services far more rapidly than it will be possible for them to increase their individual collections, or their space, or their personnel. They can increase their performance greatly, I am convinced, if they will do what they can realistically do to make of their total resources a single resource and of their services an integrated national service. The way will be open for such an achievement only if we librarians complete a great many pieces of unfinished business. It is to some of these items of our common affairs that I should like to direct your attention.

The major areas of library activity in which basic problems await solution by cooperative library effort seem to me to be four in number: library resources, reference services, administration, and international activities.

First, there is the unending problem of strengthening our library resources, both in terms of our collections and the tools which provide immediate and convenient access to them. For several years now librarians have been seriously discussing the waste of duplication in our library collecting activities, and the resultant lack of comprehensive coverage of materials, particularly foreign publications, which are required for present and prospective research programs. The beginning of a cooperative attempt to 
correct this situation is, of course, represented by the Farmington Plan, but further measures will be required if we are to achieve even the preliminary target of having in this country at least one copy of all materials of research value, no matter where published. We will have to go even further than that before we can justifiably be satisfied that we can provide researchers readily with what they require in work they are performing in the national interest. That, as you know, is a large order, and one which cannot be filled without continuing and increasing cooperation on the part of the entire library profession. The success of the Documents Expediting Project, which was organized a few years ago to facilitate the distribution of difficult-toget U.S. government documents to American research libraries, is an example of what can be done by a unified but cooperative acquisitions effort.

It is time for librarians to give more attention to the question: "What should be the over-all acquisitions policy of our research libraries?" What needs to be acquired in terms of the total collections of our research libraries? Obviously, we will have no firm framework within which to make cooperative arrangements until we have agreed upon a comprehensive answer to this question. The Library of Congress, despite its own enormous acquisitions responsibilities and its highly advantageous opportunities for acquiring foreign publications, is very much aware of the essential need for the cooperative determination of a national program and the assignment of parts of the total responsibility to many institutions, with itself taking only a part, even though that part may be greater than that of any other single library. The current critical situation of our nation compels us to bestir ourselves to face this problem squarely and realistically. Every day we delay action represents irretrievable opportunities lost. At this very moment events are occurring in other parts of the world which will prevent the acquisition of published data, basic to our understanding of some problem we must face, which could have been secured yesterday.

As I see the situation, the unsatisfied research needs of our country today are principally in two fields. The first is science, and the second concerns those areas of the world about which we have not bothered much before, particularly the Slavic, the Middle Eastern and the Far Eastern countries. Already we are paying the penalty for years of failure in building comprehensive and current collections in these fields. Some of us have been aware of these weaknesses, and have made considerable progress to correct them.

An important step was taken recently to develop a workable national program in the appointment by the Association of $\mathrm{Re}$ search Libraries of a Committee on $\mathrm{Na}$ tional Needs. Under the able chairmanship of Donald Coney, librarian of the University of California (Berkeley), this committee has had a two-day meeting in Washington where it discussed with officers of government their urgent research requirements. From there the committee will proceed to the discovery of deficiencies in present capacity to meet the requirements, and measures for dealing with them.

Perhaps as important as resources of material are the tools of access to the material. In the Library of Congress (and you will pardon me for the ignorance which requires me to select most of these illustrations from my own institution) we have attempted to meet this need in part by the publication of the list of Serial Titles Newly Received (the future of which is still undecided in view of inadequate financial support of this publication) and the 
Checklist of Russian Accessions, first inaugurated to meet demands from federal agencies, but which has since proved its value to scholars outside the government working with Soviet materials.

Serials have long presented complex problems to libraries, and the need for a revised and up-to-date union list has long been recognized. It is the matter of finding a quick and economical method of compiling such a list that stumps the experts. Some of you may be familiar with the exploratory work that has been done looking toward the possibility of producing such a union list on punched cards. The response to feelers on this subject has been encouraging, and it is hoped soon to lay more concrete proposals for cooperative effort before the library profession. I believe a great step forward in subject bibliography as well as location services can be made by a determined, cooperative effort along the lines we have been exploring.

Adequate catalog controls and bibliographical apparatus are as important resources of a library as are the collections. Processing problems, like processing arrearages, seem to be constant on the librarians' agenda of business for tomorrow. We librarians have made significant strides forward in our battle with classification schedules and classification codes. We have worried long and late about devising cataloging short cuts, simpler descriptive entries, fewer cross references and less cumbersome subject headings. In this my colleagues at the Library of Congress have actively participated. They have experimented with full cataloging, brief cataloging, deferred cataloging, and some of the materials they are simply piling up, uncataloged, to struggle with in the future. The hard work of thinking our collective way through these problems to more adequate solutions must proceed, and it must proceed in a democratic and cooperative context.

Indexing, too, is gaining a higher place in the list of bibliographical problems with which librarians must deal. The time has not arrived yet when librarians in general are willing to admit indexing as one of their leading responsibilities. For too long this vital bibliographical function has been left almost entirely to the uncoordinated, partial, and to some degree unprofessional efforts of commercial enterprise, company interests and voluntary organizations of scholars and professional workers, with the result that we have failed to provide tools which will enable scholars in all important subject areas to find late material which has appeared in a pamphlet, a periodical, or a government document. The special librarians, bless them, have done far more than librarians in general to recognize the value and importance of current indexing controls, and indeed the necessity of leadership by the library profession in this work.

Abstracting, likewise, has been a neglected function. We all know that the abstracting of current literature in individual subject fields is woefully inadequate in coverage, and in general far from current. I say that librarians have a responsibility to see that a better job is done, and that the task is not left to a few organizations and groups. We must accept the fact that this is a problem world-wide in scope, and that in preparation for dealing with it effectively in terms of coordinated effort with other countries, we must put our own house in order.

Unesco has done much in a short time to call attention to the importance of adequate bibliographical controls. It has given activities in this field an important place in its program and has organized an international committee on bibliography and 
documentation. But vision and support from all librarians is necessary if we are to make the essential progress in an area in which we have yet to discover a wholly practical and comprehensive plan of action. In the past two years a bibliographical seminar has been meeting with me in the Library of Congress and we have had some interesting discussions about the degree to which nations should accept responsibilities for developing current national bibliographies of their respective publications. The library takes pride in the contribution to this objective which its own new publications, the Subject Catalog and the Author Catalog, represent.

At this moment in our history when maximum economies and maximum controls over material are both of great importance, it is the responsibility of every major library to plan its cataloging and bibliographical program in such a way that its products will provide the greatest possible contribution to both national and universal bibliographical control.

As important though perhaps not as neglected an area of library activity is the matter of the services we give on our resources. The service function is usually one of the last activities to feel the effect of reduced budgets and personnel cuts. We may have to curtail our acquisitions program; more books may go into cataloging arrearages than to assigned places on the shelves; yet most of us are inclined to the view that materials must keep moving from shelf to reader, even though they may not be the latest or best materials, if we are to continue to have support from our users.

During the past year we have had to face this problem squarely at the Library of Congress. When the Appropriations Committee decided nearly a year ago that we should strengthen our small corps of area specialists and make a beginning on the science front by internal readjustments, my colleagues and I came to the conclusion, very reluctantly I must admit, that the ax would have to fall heaviest on the hours of public service. Accordingly, schedules were rearranged and service of materials from the shelves was discontinued after 5:30 P.M. Reading rooms remained open until Io:oo P.M., however, and readers could arrange in advance to have books left for them to pick up at the service desks. There were complaints of course, but fewer than had been expected, and the change has been fairly well accepted.

Another unsolved problem having to do with service is the matter of defining the area of unpaid and paid reference service. Perhaps I am more conscious of this than some of you because sometimes when I go before congressional committees in support of the library's budget requests, somebody asks me this question: "Doctor, why can't you ask these people to pay you for the special services you render them?" We have struggled with the problem and recognize that much useful service could be given (service which must now be refused and which in general libraries expect users to do for themselves) if a workable system of financing it could be developed.

We need to give more thought also to providing greater facilities to serious investigators pursuing studies at a high level, often in connection with a federal or university-sponsored program. This is one of our most pressing problems at the Library of Congress. Researchers from important agencies of government have been accommodated, with space and materials, but the space available has not always been the most conducive to scholarly work and the materials on hand were not always recent materials. There needs to be a systematic attack on achieving a better coordination between our acquisitions policies, 
our cataloging and bibliographical controls, and the needs of those who labor at our study desks and in our study rooms.

The urgency of such an effort is well demonstrated today. In any time of crisis we will see shifts in the foci of research interests in our universities and in our laboratories which will affect the programs of libraries. We must make certain that our institutions anticipate new requirements and equip themselves to meet them, in advance of the critical stage.

Turning now to the large area of administration, we are confronted immediately with the unpleasant but ever-present problem of securing adequate financial support for library activities. It is obvious that the goals we have set for ourselves cannot be achieved without more money, and thus we come to the problem of determining our financial needs and how best to justify them. Here it is essential that libraries give full attention to a re-evaluation of their objectives and to a realistic scheduling of priorities for carrying them out. They must study their essential services and resources and be able to defend fully, and fight for when necessary, appropriations adequate to maintain or strengthen these services and resources at a time when every expenditure is bound to be closely scrutinized. It is the individual library's responsibility to see that its funds are sufficient to meet the urgent need. There must be willingness to call to the attention of appropriating bodies those important areas where resources and services are pathetically poor or nonexistent. Explanations of needs must be presented on the basis of the best thinking available in the library profession. Arguments must become so compelling that boards of trustees and other appropriating bodies will sympathetically listen to and quickly appreciate the validity of the library's claims for more funds.
Salaries of librarians, still disgracefully low in many parts of the country, can be lifted only by the constant and courageous effort of fellow librarians. Much can be done by comparison of salary tables to determine standards of compensation which appropriation agencies will respect.

Buildings and equipment required for the best kind of library service should be a matter of vigilant study. The relation of working environment to productivity has taken on a new significance in recent years and librarians, no less than other administrators, must become aware of the improvements in service and increases in production which can be traced to a new shade of paint, a new style of furniture, or a new resolution of the problem of noise or light. We have become so modern in the Library of Congress that we have even considered the possibility of installing Muzak in the Card Division to speed up the filling of card orders for other libraries. The Congress has not yet decided to let us make the experiment, but according to the surveys of routine operations where such installations have been made, card drawing would pick up considerably if accompanied by some syncopated rhythm or even be-bop, although there are some who wonder if the right cards would be drawn!

Then there are matters of library organization, training of library personnel, developing manuals of procedures, arranging for more adequate reporting of library activities (including statistics!), all of which require continuing attention if we are to make the greatest possible progress.

We come then to the last broad areathe matter of international relations-an area in which libraries are having to face an increasingly important responsibility. More people in more parts of the world are willing to admit that libraries are vital (Continued on page 364 ) 
some rare books. Librarians could not possibly have added books to their collections for the past 100 or 150 years without inadvertently accumulating a number of books that are now considered rare. Possibly the first thing a college librarian should do in deciding on a rare books policy is (I) determine what a rare book is ${ }^{6}$ and (2) do something about segregating the rare books in his library so they may be adequately handled.

Just as every long-established college library has rare books, so may they also have special collections, although they may not be segregated and immediately recognized.

Other important possibilities for developing special collections, rare books and gifts exist.

6 "Rare Book Code of the University of California at Los Angeles Library." Antiquarian Bookman, 7:20, Jan. 6, 195I. Also in College and Research Libraries, I $0: 307-08$, July 1949 .
Regional cooperative plans for the development of subject collections, for example, are important. Such questions as the following suggest avenues of approach that should be considered: Why buy rare books at all when the same material may be had on microfilm or microcards at a fraction of the cost of the originals? What is the best method of making friends of the library and alumni aware of library needs? What other sources for gifts should be considered? To what extent does publicity about existing collections influence gifts? What are the possibilities of cooperative storage and service as a solution to the special collections problem?

It is often true that "them as has, gets." If you make a start, and your project is a worthy one, support may come from unexpected sources.

\section{The Librarians' Agenda of Unfinished Business}

\section{(Continued from page 313)}

to the good life. The critical requirements today of libraries in Europe and Asia, in their struggle to resume activities, offer a great challenge to our own institutions to aid in the unceasing effort of providing books, periodicals, training facilities, personnel, and library equipment. Libraries have been recognized as an effective instrument in the Point Four program for technical assistance to economically underdeveloped areas, for they offer an organized means of disseminating technical and economic information essential to the relief and economic advancement of those areas. The United States Book Exchange has demonstrated successfully the need for a permanent national organization devoted to the collection and distribution of books here and abroad. The exchange arrangements of our libraries for books and personnel offer continued opportunity to strengthen ourselves as well as to strengthen our neighbors.

It is agreed, then, that libraries, which serve individuals and groups of every description from the laboratory to the scholar's study, from the public school to the woman's club, are a fundamental factor in maintaining and strengthening the fabric of civilization. They are engaged in a common purpose and they share a common goal. To this end they must labor without discouragement on the problems which have been reviewed in this recital, and on others of which these are but samples. They must abandon forever inertia and indifference. They must continue, instead, to face, with calm and quiet courage, their responsibility of service in the great task before us all-the task of surviving as free nations in a world yet to be attained of free men and free women. 